POLIIICAL ECONOMY RESEARCH INSTIIUIE

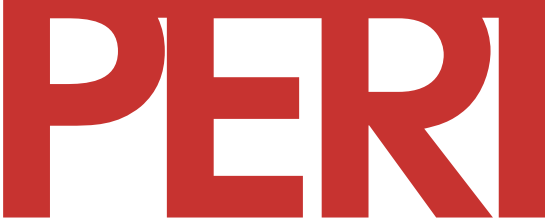

University of Massachusetts Amherst

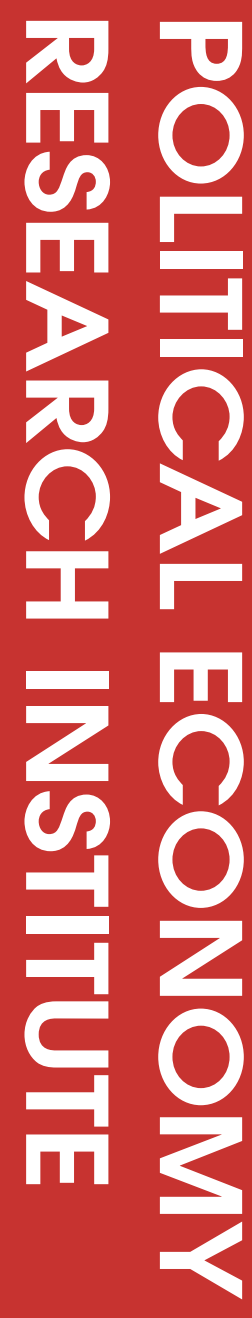

\title{
Employment-Oriented Central Bank Policy in an Integrated World Economy: A Reform Proposal for South Africa
}

\author{
Gerald Epstein
}

2002

10th floor Thompson Hall University of Massachusetts Amherst, MA, 01003-7510 Telephone: (413) 545-6355 Facsimile: (413) 545-2921 Email:peri@econs.umass.edu Website:

http://www.umass.edu/peri/

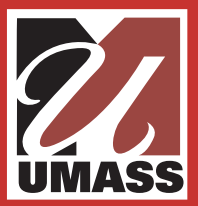




\section{Employment-Oriented Central Bank Policy in an Integrated World Economy: \\ A Reform Proposal for South Africa}

\section{Gerald Epstein Professor of Economics and \\ Co-Director, Political Economy Research Institute (PERI) \\ University of Massachusetts, Amherst \\ Amherst, MA 01003}

April 5, 2002; this version, June, 2002

Prepared for The Public Finance and Monetary Policy Chamber of the National Economic Development and Labour Council (Nedlac), Johannesburg, South Africa, April 5, 2002 The author thanks James Heintz whose knowledge and assistance was extensive and invaluable; Bob Pollin, for many useful discussions; and Andong Zhu, for help with data. All remaining errors are of my own making. 


\begin{abstract}
The South African Reserve Bank and Ministry of Finance have adopted inflation targeting and the gradual relaxation of exchange controls (along with control of public spending and financial liberalization) as the foundation of their economic policy in an attempt to win the confidence of foreign investors and to attract more foreign investment. However, this policy has not succeded in generating employment growth or investment. Instead, it has contributed to high real interest rates and relative stagnation.

In order to improve central bank and capital management policies and have them contribute more to solving the fundamental problems of unemployment and poverty facing the South African economy, three reforms should be undertaken:

1) The Reserve Bank should scrap its inflation targeting approach and adopt a more even handed approach which would target employment growth subject to an inflation constraint.

2) Rather than loosening the exchange controls system, the Reserve Bank and Ministry of Finance should enforcethe existing controls more strictly, and explore other ways, such as transaction taxes and speed-bumps, to further insulate South African macroeconomic policy from global pressures.

3) The South African government should implement other policies and institutions, such as special lending windows, underwriting facilities, asset based reserve requirements and subsidized credit, to further insulate the South African financial markets from the international capital markets and channel credit to employment generating and socially productive activities. This will correct a serious market failure in which international financial markets fail to take into account the social rates of return available on productive investments in South Africa.
\end{abstract}




\section{Introduction}

\subsection{GEAR and the Washington Consensus}

In 1996, the South African Department of Finance released its macroeconomic strategy, dubbed "Growth, Employment and Redistribution" (GEAR). GEAR is similar to the macroeconomic frameworks developed by the International Monetary Fund (IMF), in collaboration with the U.S. Treasury and is based on similar premises: the key to achieving employment growth and a rapid increase in living standards is to win the confidence of both domestic and foreign investors. To do that, macroeconomic policy must, first and foremost, reduce budget deficits to sustainable levels, achieve a low inflation rate through tight monetary policy focused on inflation control, and liberalize financial markets in order to achieve positive real rates of interest and to welcome foreign investment flows. To implement this liberalization, the government eliminated the dual exchange rate system (the so-called "financial rand") and, over time, loosened the foreign exchange control system. Later, the central bank took the additional step of adopting an "Inflation Targeting Framework" as recommended by the IMF and others.

Looking back over the last six years, however, we see that the GEAR policies solidly conforming to the so-called "Washington Consensus" macroeconomic approach was implemented with mixed results, at best. The policy succeeded in reducing inflation; the budget deficit fell; the current account deficit fell; and real interest rates rose. But real growth of GDP has stagnated; investment as a share of GDP is low by international standards; foreign inflows of foreign direct investment are modest at best; and the Rand fluctuated tremendously and declined precipitously in the last year. Most problematic of all, employment growth fell, poverty rates are high and unemployment rates stand at over $40 \%$.

To put it starkly, the government played by the rules of the neo-liberal regime, put the economy's "fundamentals" in order and made the South African economy investor friendly. But despite all its efforts, the investors stayed away, and most of the South African population has failed to achieve the economic gains they expected from GEAR.

In retrospect, this outcome should not be very surprising. The success rate for "Washington Consensus" or "neo-liberal" policies is not all that high, especially when it comes to their impact on employment, poverty and productive investment.(see Taylor, 2001 , for a review). Of course, there are success stories, but they appear to be more the exception than the rule, and often, when one looks more closely at these cases, the policies they have implemented have a heavy dose of non-consensus elements thrown into them. (Amsden, 2001; Chang, 2002)

There are four fundamental problems with the neo-liberal approach, with the importance of these problems varying from case to case. 
First, and perhaps most important in the case of South Africa, the neo-liberal policies of austerity and liberalization, designed to improve the investment climate by lowering inflation and reducing budget deficits, in fact worsen investment in other ways. In particular, by leading to low growth, worse inequality, these policies fail to significantly reduce social tension and instability. The net result is no improved climate for investment, and increased poverty and inequality. (Heintz, 2002).

Second, the policy of austerity and liberalization assumes that aggregate demand will take care of itself. But in fact, maintaining aggregate demand must be a crucial component of any sensible macroeconomic policy.

Third, the theory behind the rush to financial liberalization assumes that financial markets are efficient and stable, and will allocate resources to their best uses. Moreover, it assumes that high real interest rates will contribute more to investment by inducing increased saving, than it will detract from investment by increasing the cost of borrowing. However, as the world lurches from one financial crisis to another - from Malaysia to Argentina to Enron - even advocates' faith in the efficiency and stability of liberalized financial markets is wearing thin.

Fourth, and perhaps the most fundamental problem, is the outward-oriented nature of the whole strategy. In many cases, the Washington Consensus approach depends on the cooperation of foreign actors and markets: exports are supposed to be a key source of demand; foreign savings are supposed to generate the supply of finance; foreign direct investment (FDI) is supposed to generate know how, technology and marketing channels; and imports are supposed to create the competition that will keep domestic producers working hard, innovating and charging world prices for their products. However, most countries have found that depending on the foreign sector as the cornerstone of its development strategy is very risky. Export markets come and go with the business cycle, with the state of competition from other developing countries - many of whom are trying to implement the same strategy - and with the politics of protectionism in the developed world. Moreover, most FDI going to developing countries flows to a relatively small subset of them; and finally, as noted above, portfolio flows are fickle and sometimes destructive.

\section{2 High Real Interest Rates, Inflation Targeting and Exchange Controls}

One of the stubborn and problematic outcomes of this macroeconomic policy, and one of the main topics of this paper, is the high real interest rates that confront the South African economy today. As Table 1 below shows, short term real interest rates rose from $1.2 \%$ in the period 1950-69, to $5.6 \%$ in 1990-2000, while long term real interest rates increased from $1.9 \%$ to $5.7 \%$ over the same period.

I argue in this paper that the main factors which have contributed to the high real interest rates, apart from international factors over which the South African authorities

have no control, are: first, the inflation targeting framework adopted by the central bank, which has oriented monetary policy exclusively toward reducing inflation rather than 
toward supporting employment growth; second, the loosening of exchange controls which have made domestic interest rates conform much more closely to the demands of the international financial markets rather than to the needs of the domestic economy; and third, financial liberalization which has freed up interest rates and increased financial innovations which have increased the demands for consumer credit and more speculative uses, as well.

In this paper, I will focus on the first two of these factors. I argue that the central bank's focus on fighting inflation, to the exclusion of other important factors such as employment growth, is partly to blame for the high interest rates, the disappointing employment outcomes and the relatively low levels of economic growth. As a result, I argue that the South African Reserve Bank should adopt a different, more balanced approach, in which an employment growth target is added to its target list. This would bring South African Central Bank policy closer to international practice, in which central banks try to achieve some balance among important targets, for example unemployment and inflation. (Blinder, 1998) International evidence, which I will discuss in some detail, indicates that inflation targeting fails to achieve the promise its advocates have claimed for it and that other approaches are better suited for a country like South Africa with such high levels of unemployment. This approach would lead the South African Reserve Bank, in the appropriate circumstances, to lower interest rates to support more rapid growth of output and employment.

If the South African Reserve Bank were to pursue a more expansionary monetary policy, concern would be raised that this could lead to a flight from the Rand, compounding the Rand's current problems. To counteract this threat, the South African Government should strengthen the exchange controls.

1.3 Political Risk and Insulating the Domestic Financial Market from the International Capital Market

It might be objected that this approach to macroeconomic policy will fail because it will drive away crucial foreign saving from the South African economy. But it is more correct to turn this point of view on its head. The current macroeconomic framework has failed to attract significant amounts of foreign investment and stabilize the Rand, despite following the prescriptions of the Washington Consensus. An important reason for this failure is that the policies adopted have not reduced South Africa's enormous inequalities and political tensions related to them, and may, indeed, have made them worse (Heintz, 2001). As a result, political risk appears to foreign creditors to be high and unstable; the result is a high "country premium" on interest rates, and a fragile commitment to holding Rand denominated assets. Unless these basic inequalities and political problems can be mitigated, "finance friendly" macroeconomic policies will not suffice to attract large amounts of "patient" foreign capital, and indeed, by leading to slower economic growth and possibly worse inequalities, will themselves reduce the willingness of foreigners to invest in the economy. 
In the meantime, then, it is important to find ways to insulate the cost and availability of credit in the South African economy from the vagaries of the international capital markets. Local institutions and markets know better than foreign ones who the good credit risks are and the South African government knows better than foreign financiers what are the positive social and network externalities that can be created from making more credit available to individuals, groups and communities in South Africa. Hence, as a complement to a more employment oriented monetary policy and tightened capital controls, more tools for credit allocation and subsidies will be needed to make sure credit gets to those South Africans who can make the most productive use of it to reduce poverty, generate employment, increase productivity and reduce inequality.

\subsection{Outline of the paper}

The rest of the paper is organized as follows:

In the next section I will discuss the role of the international financial sector and suggest that useful foreign finance follows domestic economic success and does not usually lead it. When foreign finance leads the economy, the impact is more often instability and crisis not sustained economic growth. Hence, it is very risky for the South African government to base its macroeconomic policy on the desire to please foreign finance, because it is likely to win, at best a phyric victory. Instead, it should focus on generating more employment, equality and growth in the South African Economy and if it succeeds, the evidence suggests that the finance will follow.

In the following section of the paper, I present data on real interest rates in South Africa over time and in international perspective. I discuss the causes of the high real interest rates and their effects. Section 4, critiques the inflation targeting framework of the South African Reserve Bank, while in section 5 I suggest an alternative approach which incorporates employment targeting as a key target of monetary policy. In section 6, I will take up the issue of exchange controls and discuss various approaches that have been used in other countries to enhance the autonomy of domestic macroeconomic policy. The final section concludes.

\section{Foreign Finance Follows Success; It Does Not Often Lead It}

\subsection{Recent Experience With Capital Account Liberalization, Crises and Growth}

Since the 1980's, developing countries have been urged to liberalize their capital markets and to adopt capital friendly reforms with the expectation that they would be able to attract foreign savings to aid in their development process. However, for the most part, this promise has not been fulfilled. There are three main reasons for the disappointment: First, there has been very little net transfer of funds from the developed countries to the developing countries since 1980, and by contrast, much less than during the first period of globalization in the late $19^{\text {th }}$ century. Second, capital account liberalization has been associated with frequent financial crises, more frequent, in fact, than during the late $19^{\text {th }}$ 
century. Third, foreign direct investment, while possibly more stable than portfolio investment, is highly concentrated among countries and even its benefits are unclear.

\subsubsection{A lot of gross flows but few net flows to developing countries}

As Obstfeld and Taylor (2002) show, current foreign capital asset flows is "more about hedging and risk sharing than it is about long-term finance and the mediation of saving supply and investment demand between countries. In the latter sense, we have never come close to recapturing the heady time of the pre-1914 era when a creditor like Britain could persist for years in satisfying half of its accumulation of assets with foreign capital, or a debtor like Argentina could similarly go on for years generating liabilities of which one half were taken up by foreigners. Instead, still to a very great extent today, a country's net wealth will depend, for accumulation, on the provision of financing from domestic rather than foreign sources." (p. 58)

Indeed, while gross flows of capital have been increasing rapidly, and are quite large in the 1990 's compared with the late $20^{\text {th }}$ century, when assets and liabilities are compared and the net flow of capital is calculated, one sees that the net foreign asset position (or net foreign liability position) have remained very low since 1980 and, in fact, have declined relative to GDP over the period. (Obstfeld and Taylor, 2002; Baker, Epstein and Pollin, 1998; Epstein and Gintis, 1992)

Thus, say, Obstfeld and Taylor: "...for all the suggestions that we have returned to a pre-1914 type of global capital market, here is one major qualitative difference:...Today's foreign asset distribution is much more about asset "swapping" by rich countries....than it is about the accumulation of large one way positions - a critical component of the development process in poorer countries in standard textbook treatments". (p. 58).

This problem is especially acute for developing countries. The share of less developed countries (LDC's) in global liabilities is now at an all time low. In 1900, LDCs in Asia, Latin America and Africa accounted for 33 percent of global liabilities. In the 1990 's, by contrast, they accounted for only 11 percent. As Obstfeld and Taylor (2002) put it, "Globalized capital markets are back, but with a difference: capital transactions seems to be mostly a rich-rich affair, a process of "diversification finance" rather than "development finance". The creditor-debtor country pairs involved are more rich-rich than rich-poor, and today's foreign investment in the poorest developing countries lags far behind the levels attained at the start of the last century." (Obstfeld and Taylor, 2002, p. 59).

The lesson of these data is this: at the beginning of the $21^{\text {st }}$ century, foreign finance follows successful development. It does not tend to lead it. It behooves developing countries to muster their internal sources of development - especially their underutilized resources, rather than building their economic structure around the hope of attracting finance from abroad. 


\subsubsection{Financial Crises}

Developing countries have liberalized and followed the Washington Consensus policies to attract foreign savings. Not only have they, in general, attracted little in the way of net, long term financing, as discussed above. But they have made themselves vulnerable to financial crises. These crises have occurred with increasing frequency relative to the earlier period of globalization in the late $19^{\text {th }}$ century.

According to Barry Eichengreen (2001), a randomly selected country in his pre1914 sample had a $5 \%$ chance of having a financial crisis. In the post-1973 period, by contrast, the probablility of a randomly selected country experiencing a crisis in a randomly selected year is twice as high. He distinguishes between purely currency crises and banking crises. When both happen, Eichengreen terms them "twin crises". In the post-1973 period, currency crises have been much more frequent than in the pre 1914 period, banking crises have stayed about the same, so the prevalence of "twin crises" have greatly increased. Moreover, in many cases, financial crises have occurred even in countries whose "fundamentals", such as budget deficits and current account deficits, were relatively sound. Countries that were vulnerable had followed inappropriate financial liberalization policies, had allowed their private sectors to borrow high amounts of short term debt, were too open to short term capital flows, or were simply hit by contagion (Chang and Velasco, 2001; Rodrik and Velasco, 1999).

In light of these results, it is little wonder that it is hard to find, in large cross sections, a positive connection between capital account liberalization and economic growth, investment or other improvements in the real economy. (Rodrik, 1998; Eichengreen, 2002). While it is incorrect to say that capital account liberalization always leads to disaster or fails to help the economy, it is also true that there is very strong evidence to suggest that in many cases, it does more harm than good.

\subsection{Foreign Direct Investment}

Partly in response to the disappointments associated with portfolio inflows, the international institutions and domestic policy makers increasingly see foreign direct investment as the investment of choice. Many believe that FDI is more stable than portfolio investment, generates employment, and economic growth, transfers technology and helps to tap markets.

Most of the empirical research on the effects of FDI run cross country growth equations and look at the impact of FDI on growth. Many find a positive impact (see Braunstein and Epstein, 2002, for a survey). However, these studies are plagued by problems of causality: does growth cause FDI or does FDI cause growth? They also are hindered by possible omitted variable bias: is some variable leading countries to have both more growth and more FDI?

Gordon Hanson (2001), in an UNCTAD study of the benefits of FDI for developing countries, is not very confident about the findings of these types of studies. 
He argues that although the early empirical literature was optimistic about the impact of MNCs on host-country productivity, its findings are open to the sorts of criticisms described above about the direction of causality as well as omitted variables, such as mentioned above in terms of policy. ${ }^{1} \mathrm{He}$ describes more recent and promising work done on the micro-level, where time series data of manufacturing plants provides solutions to these empirical problems by showing how the productivity of domestic plants changes over time in response to the presence of MNCs. Hanson concludes that micro-level data undermines empirical support for productivity spillovers from FDI, perhaps indicating that MNCs confine competing domestic firms to less profitable segments of industry.

Whether or not FDI contributes indirectly to growth through productivity, there is still the question of how it may affect domestic investment, whether FDI stimulates or crowds out domestic investment. Using panel data for the period 1970-96 in three developing regions, Asia, Africa and Latin America, Manuel Agosin and Ricardo Mayer (2000) did an econometric study of whether foreign investment crowds in domestic investment. Their results indicate that in Asia, and to a lesser extent in Africa, there has been strong crowding in of domestic investment by FDI. In Latin America, FDI has had a strong crowding out effect. Braunstein and Epstein find that FDI crowds out domestic investment in China, as well. (ibid., 2002)

Not only are the benefits of FDI possibly less than is often believed, as I showed above it tends to flow to rich countries and only a handful of developing countries. Both inward and outward flows are highly concentrated. Inward FDI is concentrated in a handful of countries -- ten countries received 74\% of all global FDI flows in 1999. Among the developing countries, only ten developing countries received $80 \%$ of total FDI flows to the developing world in this same period. More importantly, as the World Investment Report notes, there are no signs that the concentration of FDI across countries has been declining over time. (See Burke and Epstein, 2001). In the developing world, as is well known, China and other Asian countries, including Taiwan, Hong Kong, Thailand, Malaysia and Singapore get a significant share of the developing world's FDI. Indeed, if China is excluded from the data, the share of inward stock held by the developing world has been more or less stagnant over the last 20 years, at a little less than a quarter.

To be sure, some FDI does come to South Africa, and, presumably, does generate some benefits. The question for monetary policy is: can South Africa attract more, high quality FDI by keeping inflation low? The evidence suggests that moderate rates of inflation are not an important determinant of foreign direct investment flows.

Table 1 presents some econometric estimates of the determinants of foreign direct investment. This is a panel data set run on 70 countries between the period of 1960 and 1977. The dependent variable is the share of FDI in gross domestic product (GDP). The first column includes all inflation rates. The third includes only those observations with

\footnotetext{
${ }^{1}$ This section is taken from Braunstein and Epstein, 2002.
} 
inflation less than $20 \%$ and the final column includes only those observations with inflation greater than $50 \%$.

The results indicate that inflation does NOT have a negative impact on FDI flows. If anything, moderate rates of inflation are associated with higher flows. GNP growth and and export growth are two factors which attract FDI and corruption discourages it, especially in high inflation countries and time periods.

Hence, while keeping inflation at a moderate rate may have some benefits, attracting foreign direct investment does not seem to be one of them 
Table 1

The Impact of Inflation and Growth on

Foreign Direct Investment (FDI)

(Dependent variable: FDI as share of GDP)

1960-1997

\begin{tabular}{|l|l|l|l|l|}
\hline $\begin{array}{l}\text { Independent } \\
\text { Variable }\end{array}$ & \multicolumn{2}{l|}{$\begin{array}{l}\text { Any inflation } \\
\text { rate }\end{array}$} & $\begin{array}{l}\text { Inflation } \\
<20 \%\end{array}$ & $\begin{array}{l}\text { Inflation } \\
>50 \%\end{array}$ \\
\hline & & & & \\
\hline inflation & .009 & .009 & .027 & .01 \\
& $(4.5)$ & $(2.3)$ & $(1.7)$ & $(3.5)$ \\
\hline gnp growth & .124 & -.004 & .036 & .227 \\
& $(4.7)$ & $(-.17)$ & $(1.3)$ & $(5.3)$ \\
\hline gdi growth & -.005 & .003 & -.004 & -.01 \\
& $(-.74)$ & $(.60)$ & $(-.64)$ & $(-1.1)$ \\
\hline export growth & .024 & .001 & 0.0 & .03 \\
& $(2.5)$ & $(-.06)$ & & $(2.5)$ \\
\hline corruption & .096 & -.001 & -.05 & .19 \\
& $(3.54)$ & $(-.06)$ & $(-1.07)$ & $(5.07)$ \\
\hline central bank & & .504 & & \\
independence & & $(.59)$ & & .14 \\
\hline Adjusted R-sq & .13 & .02 & .03 & 492 \\
\hline N & 690 & 266 & 101 & \\
\hline
\end{tabular}

t-statistics in parentheses. For data sources see: Epstein (2002).

gdi = gross domestic investment; corruption: the higher the number, the more corrupt the government and economy; central bank independence: the higher the number the less independent is the central bank. 


\subsection{Does Foreign Investment reduce financing constraints?}

Finally, the question arises as to whether portfolio and/or foreign direct investment reduce financing constraints facing firms. The evidence on this topic is mixed. It is difficult to get the micro level data one would need to properly answer this question. I have already mentioned the study of crowding in and crowding out which suggests that in some cases, FDI crowds out domestic investment.

Several recent papers (Harrison, Love and McMillan (2001) and Harrison and McMillan (2002) give conflicting views. Both papers have micro data on firm investment and use country level data on FDI and portfolio investment. The first paper finds that portfolio investment has no impact on financing constraints, but that FDI does seem to reduce firm financing constraints. The second paper, however, looks at similar data but just for the Ivory Coast. In the case of the Ivory Coast, more FDI seems to increase the financing constraints facing domestic firms, presumably because foreign firms compete for domestic bank credit and other financing.

While much more work needs to be done to understand the relationship between FDI, and firm financing constraints, these results give one pause: they cast doubt on any simple relationship between portfolio investment, FDI and firm financing constraints.

\subsection{Conclusion: Foreign Capital and Economic Development}

This section has suggested that it is not wise for a country like South Africa to make attracting and retaining foreign investment a cornerstone of its macroeconomic framework. International finance tends to follow, not lead, economic growth and development. And opening oneself to the international capital markets poses dangers, as has become increasingly apparent in recent years.

This does not mean that it is wise, necessarily, to cut oneself off entirely from the international capital market. It does mean, however, that tapping the international financial system must be seen as a means, and probably a subsidiary means towards the end of economic development and growth, not as the foundation of the policy.

Among the problems in opening up to the international capital markets, is that the domestic interest rates become more closely tied to interest rates on the world market. As I suggest in the next section, this can help explain why, in recent years, real interest rates have been so high in South Africa; it also suggests that the real interest rates are inefficiently high.

\section{High Real Interest Rates}

3.1 High Real Interest Rates In Historical and International Perspective 
The problem of high real interest rates is not unique to South Africa. As Table 2 shows, during the last decade or so in the major financial markets of the world, real interest rates have risen substantially relative to previous decades, even while economic growth, inflation and profitability have fallen.

Table 2: Real Interest Rates, and other Macro Variables Since 1950

(Average of USA, UK, Germany and France)

\begin{tabular}{|l|l|l|l|l|l|}
\hline & $\begin{array}{l}\text { Mean real } \\
\text { short rate } \\
(\%)\end{array}$ & $\begin{array}{l}\text { Standard } \\
\text { deviation, } \\
(\%)\end{array}$ & $\begin{array}{l}\text { Inflation rate } \\
(\% \text { per annum })\end{array}$ & $\begin{array}{l}\text { GDP Growth } \\
(\% \text { per annum })\end{array}$ & $\begin{array}{l}\text { Profit Rate } \\
(\%)\end{array}$ \\
\hline $1951-68$ & 0.7 & 2.6 & 3.2 & 4.5 & 15.0 \\
\hline $1969-79$ & 0.3 & 2.3 & 7.6 & 3.3 & 9.3 \\
\hline $1980-97$ & 3.8 & 1.9 & 3.0 & 2.1 & 9.3 \\
\hline
\end{tabular}

Source: Allsopp and Glyn (1999).

The 1980's and 1990's are not the only period of high interest rates in the past. As Table 3 shows, high real interest rates have characterized other periods in recent capitalist history, including during the turmoil and stagnation of the interwar period.

Table 3

Periods of High Real Rates

(Average of USA, UK, Germany and France)

\begin{tabular}{|l|l|l|l|l|}
\hline & $\begin{array}{l}\text { Mean real } \\
\text { short rate }(\%)\end{array}$ & $\begin{array}{l}\text { Standard deviation } \\
(\%)\end{array}$ & $\begin{array}{l}\text { Inflation rate } \\
(\% \text { p.a. })\end{array}$ & $\begin{array}{l}\text { GDP growth } \\
(\% \text { p.a. })\end{array}$ \\
\hline $1875-96$ & 4.3 & 2.6 & -1.0 & 2.3 \\
\hline $1920-38$ & 3.6 & 7.6 & 0.4 & 2.2 \\
\hline $1980-97$ & 3.8 & 1.9 & 3.0 & 2.1 \\
\hline
\end{tabular}

Source: Allsopp and Glyn (1999).

Since the 1950's, as shown in more detail in table 4 below, real interest rates have varied, with many countries, including South Africa experiencing negative real interest rates in the 1970's, and then, over the next two decades, experienced a move to positive and then high real interest rates. By the last decade, 1990-2000, South Africa's interest rates, both nominal and real, were definitely at the high end of the international spectrum. South Africa's short rates, on average, were 5.6\% (higher than all of the other sample countries except New Zealand, also an inflation targeter) and its real long rate was the highest in the group, at $5.7 \%$ 
Table 4

Real Interest Rates Since 1950

\begin{tabular}{|l|c|c|c|c|c|c|c|c|c|}
\hline & SA & US & Ger. & Fr. & UK & JP & Aust & NZ & CN \\
\hline Real Short Rate: & & & & & & & & & \\
\hline $1950-69$ & 1.2 & 1.2 & 2.0 & -.6 & & 2.2 & & 1.5 & 1.5 \\
\hline $1970-79$ & -3.2 & -0.3 & 1.1 & -.3 & -8.0 & -3.1 & -2.9 & -3.3 & 0.7 \\
\hline $1980-89$ & -0.8 & 2.7 & 3.5 & 3.6 & 4.2 & 2.0 & 4.4 & 3.4 & 4.8 \\
\hline $1990-2000$ & 5.6 & 1.6 & 3.2 & 4.4 & 3.9 & .8 & 4.4 & 6.2 & 3.9 \\
\hline & & & & & & & & & \\
\hline Real Long Rate: & & & & & & & & & \\
\hline $1950-69$ & 1.9 & 2.2 & 4.4 & 0.6 & 2.0 & 2.1 & 0.3 & 0.6 & 2.2 \\
\hline $1970-79$ & -0.5 & 0.4 & 3.1 & 0.1 & -0.7 & -1.4 & -1.4 & -4.0 & 1.1 \\
\hline $1980-89$ & 0.0 & 5.0 & 4.6 & 4.4 & 3.7 & 4.0 & 4.0 & 2.0 & 5.2 \\
\hline $1990-2000$ & 5.7 & 3.6 & 4.0 & 5.1 & 4.0 & 2.4 & 2.4 & 5.8 & 5.5 \\
\hline & & & & & & & & & \\
\hline
\end{tabular}

Source: Kahn and Farrell (2002) based on IMF data.

$\mathrm{SA}=$ South Africa; US= United States; Ger. = Germany; Fr. = France; UK = United

Kingdom; JP = Japan; Aust. $=$ Australia; $\mathrm{NZ}=\mathrm{New}$ Zealand $; \mathrm{CN}=$ Canada

Table 5 presents similar data on a year-by-year basis for short term interest differentials for a number of countries, including developing countrie s such as Turkey, Brazil, Chile, Mexico and South Korea. In 2000, South Africa's short term real interest rate was higher than every country in the sample except for Brazil's. 
Table 5

Short-Term Real Interest Differentials

(South African real rates minus foreign real rates)

\begin{tabular}{|l|c|c|c|c|c|c|c|}
\hline & 1994 & 1995 & 1996 & 1997 & 1998 & 1999 & 2000 \\
\hline & & & & & & & \\
\hline SA-USA & 1.8 & 4.0 & 7.6 & 4.8 & 9.5 & 4.0 & 4.1 \\
\hline SA-Canada & -3.3 & 2.8 & 8.0 & 4.6 & 8.2 & 3.5 & 3.5 \\
\hline SA-Japan & 2.9 & 5.8 & 9.3 & 8.7 & 12.6 & 6.0 & 5.6 \\
\hline SA-UK & 1.7 & 3.8 & 6.2 & 4.0 & 8.8 & 3.3 & 3.9 \\
\hline SA-France & -0.1 & 1.6 & 7.8 & 5.3 & 9.7 & 4.6 & 4.2 \\
\hline SA-Germany & 1.4 & 3.6 & 7.8 & 6.2 & 9.9 & 4.7 & 4.5 \\
\hline SA-Greece & -5.6 & -2.7 & 1.3 & -1.5 & & -2.4 & 1.7 \\
\hline SA-Norway & -3.4 & 0.3 & 3.1 & -1.1 & 8.1 & 1.7 & 2.8 \\
\hline SA-Australia & 0.7 & 3.5 & 5.1 & 2.2 & 8.3 & 3.5 & 5.3 \\
\hline SA-NZ & -1.4 & 2.1 & 4.9 & 4.5 & 4.7 & 1.6 & 0.8 \\
\hline SA-Turkey & 55.3 & 44.5 & 40.0 & 26.2 & 30.1 & 11.7 & \\
\hline SA-Brazil & & & -1.8 & -10.6 & -13.9 & -14.6 & -3.8 \\
\hline SA-Chile & 0.3 & 0.9 & 3.5 & 1.6 & 2.6 & 1.6 & 1.3 \\
\hline SA-Mexico & -3.2 & -7.0 & 12.6 & 8.3 & 3.6 & 2.0 & 1.0 \\
\hline SA-Korea & 5.2 & 5.9 & 9.6 & 6.9 & 16.9 & 4.6 & 4.0 \\
\hline
\end{tabular}

Source: Kahn and Farrell (2002) based on IMF data.

Looking at the long term differential (table 6 below), it is clear that South Africa's real rate is substantially higher than that of every country in the sample. 
Table 6

Long-Term Real Interest Rate Differentials

(South African Rate minus foreign real rates)

\begin{tabular}{|l|c|c|c|c|c|c|c|}
\hline & 1994 & 1995 & 1996 & 1997 & 1998 & 1999 & 2000 \\
\hline & & & & & & & \\
\hline SA-USA & 1.3 & 3.7 & 4.6 & 2.1 & 4.5 & 6.3 & 5.8 \\
\hline SA-Canada & -2.6 & 1.4 & 2.2 & 1.3 & 3.8 & 5.7 & 5.3 \\
\hline SA-Japan & 2.8 & 4.9 & 6.0 & 6.2 & 7.8 & 7.6 & 6.1 \\
\hline SA-UK & 0.3 & 2.7 & 2.5 & 2.2 & 6.2 & 6.6 & 6.7 \\
\hline SA-France & 0.1 & 1.7 & 3.8 & 1.7 & 4.2 & 5.6 & 4.7 \\
\hline SA-Germany & 1.9 & 2.7 & 3.9 & 3.0 & 4.8 & 6.0 & 5.2 \\
\hline SA-Netherlands & 1.4 & 2.2 & 3.7 & 2.5 & 5.3 & 7.0 & 5.5 \\
\hline SA-Norway & 0.1 & 3.1 & 3.4 & 3.6 & 5.1 & 6.7 & 5.2 \\
\hline SA-Australia & -1.3 & 3.0 & 2.6 & -0.5 & 3.6 & 5.1 & 6.7 \\
\hline SA-NZ & 0.7 & 3.3 & 2.4 & 0.1 & 3.1 & 3.5 & 4.3 \\
\hline
\end{tabular}

Source: Kahn and Farrell (2002) based on IMF data.

\subsection{The Impact of High Real Interest Rates}

There is a lot of dispute about the impacts of high real interest rates on economic activity. In this section, I will briefly discuss four impacts: saving, investment, budget deficits and income distribution with special reference to South Africa.

\subsubsection{Saving and macroeconomic activity}

Advocates of financial liberalization argued that freeing up financial markets would have a positive impact on saving and therefore on economic growth. The mechanism would be that financial liberalization would raise real interest rates; higher real interest rates would, in turn, induce households to save more, and these savings would flow into higher investment.

Even as a theoretical matter, the positive association between higher real interest rates and saving need not hold: higher real interest rates lead to more wealth for creditors, and therefore might increase consumption as a percentage of income. For whatever reason, evidence has not been kind to the financial liberalization hypothesis. (Taylor, 1999, p. 99-102) There is little evidence that higher real interest rates lead to lower consumption spending, and therefore more saving. Moreover, there is very little evidence that higher real interest rates lead to higher rates of economic growth, as would be expected from the financial liberalization hypothesis. (Taylor, pp. 105-106). There is some evidence reported in Fry (1997) that the relationship between real interest rates and 
growth might be non-linear: there is a positive relationship at very low levels of real interest rates, but a negative relationship at higher levels. An important intervening variable is the degree of openness of the capital account. With small, open economies, an open capital account and high real interest rates can lead to over-borrowing and financial crises. This, in fact, is what has happened in many economies (Pil and Pradhan, 1997; Taylor, 2001).

In short, there is little evidence of a positive relationship between real interest rates, saving and growth, as predicted by the financial liberalization hypothesis; and there is good reason to believe that there may be a negative effect of high real interest rates on these important variables.

\subsubsection{Investment}

\subsubsection{Surveys}

We have two types of evidence on the impact of high real interest rates on investment. The first is survey evidence, where firms are simply asked, directly or indirectly, about the impact of high real interest rates on their investment plans. In the three sets of survey results that I report here, high real interest rates in South Africa are seen by firm owners/managers as a significant obstacle to firm investment and expansion.

The first set of results was drawn from a series of surveys undertaken by the World Bank in conjunction with the Johannesburg Metropolitan Council in 1999. (Lewis, 2001). The first survey sample included 325 large firms (greater than 50 employees) located in the Greater Johannesburg Metropolitan area. The CEO's were asked what they perceive as the main obstacles to their firms' growth. The three most important obstacles they cited were:

1. Crime and Theft

2. Cost of Capital or Credit

3. Depreciation and/or volatility of the Rand

As for the cost of capital, 61 percent of the firms reported being adversely affected by the higher interest rates during 1998; a smaller, but still sizeable number (30$40 \%$ ) reported that they would expand investment in response to a fall in the interest rate.

Surveys of the same type looked at a sample of small, medium and micro enterprises (SMME's), also in the greater Johannesburg Metropolitan Area, this time in 1999. (Lewis, 2001). The managers of these firms were asked to report on what conditions would be necessary for them to employ ten more workers. These firms reported that in order to expand they would need more demand and an increase in business visibility. Both conditions suggest that SMME's first and foremost need is a larger customer base. 
In addition, SMME's identified high interest rates and/or limited access to capital as important constraints on employment expansion. Limited access especially applied to younger and smaller black owned businesses (Lewis, 2001, p. 29). Firms also reported that the cost of credit was a serious concern. While one-third of businesses reported that declining interest rates made no difference to their business, the other two-thirds thought they were important. To be sure, interest rates or access to credit are not the only important factor affecting small firms, but they are significant for many of them.

Stephen Gelb from the EDGE Institute in Johannesburg reports on the National Enterprise Survey (NES), a survey of over 1400 firms in South Africa undertaken between November 1999 and February 2000, as survey designed to understand the investment behavior of these firms. (Gelb, 2001). In the sample, $66 \%$ of the firms were manufacturing firms, while $64.6 \%$ of the firms were small firms. $15 \%$ of the small firms and $9.5 \%$ of the large firms (13\% overall) had significant ownership and/or management which is not white. Over half of the firms used retained earnings as their most important source of financing, but a significant number (30\%) reported using bank loans as their most important source. (Gelb, 2001, p. 6).

Firms were given a list of 17 possible obstacles to investment and were asked to give them a point ranking on a scale of 1 to 4 where 1 meant that the obstacle was 'insurmountable' and 4 meant no impact. We focus here on the results for manufacturing firms. The key result for our purposes is this: All subgroups of manufacturing firms saw 'interest rate levels' and 'crime and social issues' as the two major obstacles to investment (Gelb, 2001, p. 8). But whereas the impact of interest rates was similar across all firms, crime and social issues seemed to be more important to the smaller firms.

While these different surveys ask somewhat different questions - with some asking about obstacles to investment and others asking about obstacles to hiring new employees -- they all touch on the issue of firm growth, and investment. A common finding is that firms perceive the cost of credit and its availability as being an important constraint on their ability to expand. This ranks first or second, with crime and social instability being the other key factor. Finally, demand for output is also seen by many firms as a major concern, as one might expect.

\subsubsection{Econometric Studies}

As is often the case when looking at the impacts of interest rates on investment, the econometric studies give evidence that sometimes conflicts with the survey evidence. Cross national evidence on the impact of real interest rates, and the cost of capital, more generally, on investment rates is weak, despite the strong theoretical and survey evidence in support of the impact. (Allsopp and Glyn, 1999; Taylor, 1999)

Of course, cross national econometric evidence only look at average behavior and the impact will vary from country to country and time to time.

Some econometric estimates of South African investment behavior, however, are no more supportive of the impact of high real interest rates on investment than the cross 
national evidence. Heintz (2002) estimates the impact of a number of factors on investment behavior in South Africa from 1971 - 1993. He found that, while the cost of capital had a negative sign, it was not statistically significant. The profit share and profit rate, on the other hand, were important determinants. Gelb (2001) carried out an investment equation on cross sectional data in 1998-1999. These results also fail to uncover a significant impact of cost of capital on investment.

However, Gibson and Van Seventer (2000) report an important role for the cost of capital, and therefore real interest rates, in their investment equation. While the coefficient is not large, it is highly significant. In their policy simulations, Gibson and Seventer find that monetary policy has a sizeable impact on investment, economic growth and employment growth through its impact on the cost of capital and therefore on real interest rates. Part of the explanation as to why some econometric studies find small or no effects for real interest rates is that interest rates operate through two channels: the pure cost of capital channel; and by affecting the amount of retained earnings and profits, after paying interest costs. If researchers are not careful, they will find that the profit and retained earnings variables are picking up some of the interest rate effects.

There is still another channel, a more indirect one, through which high real interest rates might affect investment. Both Heintz and Gelb find that political instability has a large impact on investment behavior. As we will discuss below, monetary and financial policy has an important role to play in either reducing or exacerbating these political tensions and inequalities.

\subsubsection{Budget Deficits}

So far I have focused on the impact of interest rates on private investment. But, of course, high interest rates will also affect the governments cost of borrowing money. Higher interest rates increase the government budget deficit by contributing to borrowing costs. Currently (2001/2002) the government budget deficit is $-\mathrm{R} 14142.6$ or $-1.4 \%$ of GDP. However, the primary budget is in surplus at 3.3\%. Interest payments are $\mathrm{R} 47515.1$. Increases in real interest rates raise the real cost to the government of financing its debt. Hence higher interest rates make it harder, from the perspective of the budget picture, to gain the "confidence" of the financial markets.

\subsubsection{Income Distribution}

Since the wealthy tend to hold government debt, high real interest rates worsen the income distribution as well. More generally, high real interest rates redistribute income from debtors to financial wealth holders.

\subsection{The Causes of the High Real Interest Rates in South Africa}

What causes these high real interest rates? There are three possible explanations: 
1) They are due to tight monetary policy by the Reserve Bank as part of its inflation targeting approach.

2) They are due to increases in real interest rates in other economies and/or to increased financial linkages between the South African financial markets and those abroad.

3) They are due to country risk premium assigned by the international financial markets to South Africa.

In fact, each of these is likely to have played some role in the increase in interest rates in South Africa. According to economists at the Reserve Bank, the most important factor is the inflation targeting approach adopted by the Reserve Bank (Kahn and Farrell, 2002). In an attempt to bring down inflation to the 3-6\% range, the Reserve Bank has been forced to keep a high repo rate.

As for monetary policy abroad, evidence suggests that, as South Africa has relaxed its exchange controls, its real interest rates have become more sensitive to real interest rates abroad (Kahn and Farrell, 2002). As the U.S. Federal Reserve and the European Central Bank raised interest rates in 2000-2001, this would certainly have placed upward pressure on the South African interest rates.

But South African rates remain high by international standards. This is true despite the fact that South Africa has quite good economic fundamentals (see table 8). While inflation is high, the current account balance and budget deficit as percentages of GDP are low or in line with countries that have better credit ratings. 
Table 8

South African Fundamentals In a Comparative Basis

\begin{tabular}{|l|l|l|l|l|}
\hline & $\begin{array}{l}\text { Current } \\
\text { Account/GDP }\end{array}$ & $\begin{array}{l}\text { Budget } \\
\text { Deficit/GDP }\end{array}$ & $\begin{array}{l}\text { Inflation } \\
\text { Rate }\end{array}$ & $\begin{array}{l}\text { real long term } \\
\text { interest rate }\end{array}$ \\
\hline $\begin{array}{l}\text { South } \\
\text { Africa }\end{array}$ & $-.2 \%$ & $-1.3 \%$ & 6.10 & 5.31 \\
\hline UK & -1.8 & -3.27 & .90 & 4.03 \\
\hline EU & -.2 & -10.9 & 2.0 & 2.26 \\
\hline Mexico & -3.0 & -1.95 & 5.4 & 6.84 \\
\hline
\end{tabular}

Source: OECD, Main Economic Indicators. Current Account, 2001; Budget Deficits, 1991; Mexico and EU interest rates: short-term.

It is plausible to suggest that the interest rate penalty is due to perceptions of criminal problems and political instability in South Africa, as well as a possible contagion effect from the political problems in Zimbabwe. Assuming these arguments are correct, the question becomes: is the promise and impact of inflation targeting worth the cost in terms of high real interest growth? And is inflation targeting appropriate for an economy in South Africa's situation? I believe the answer to both of these questions is no.

\section{Inflation Targeting: A Critique}

\subsection{Introduction}

Soon after being elected in 1994, the South African government decided that price stability should be the central concern of monetary policy. In 1998, the Reserve Bank adopted, for the first time, an informal inflation target range of $1-5 \%$. Then in February, 2000, the Reserve Bank adopted a formal inflation targeting approach. According to this approach the Ministry of Finance establishes the target range and the Reserve Bank chooses the instruments to achieve the target. In particular, the government chose a target of 3\%-6\% rate of increase of CPIX, which is an index of the consumer price index excluding interest costs on mortgage rates and the Reserve Bank chose the repo rate as the main instrument. (See Casteleijin, 2001).

4.2 The Principles and Problems with Inflation Targeting

\subsubsection{The Case for Inflation Targeting ${ }^{2}$}

\footnotetext{
2 This section draws extensively on several of my previous papers, including Epstein (2002) and Epstein (2000). These in turn make use of research presented in Maximov (1999a, 1999b and 1999c).
} 
According to its advocates, "full fledged" inflation targeting consists of five components: absence of other nominal anchors, such as exchange rates or nominal GDP; an institutional commitment to price stability; absence of fiscal dominance; policy (instrument) independence; and policy transparency and accountability. (Mishkin and Schmidt-Hebbel, 2001, p. 3; Bernanke, et. al. 1999). The oddest idea in this list is the notion that inflation targeting increases "accountability", a point to which I return below.

In practice, few central banks reach the "ideal" of being "full fledged" inflation targeters. But, while the implementation of inflation targeting varies from country to country, in practice the hallmark of inflation targeting is the announcement by the government, the central bank, or some combination of the two that in the future the central bank will strive to hold inflation at or near some numerically specified level. (Bernanke and Mishkin, 1997, p. 98). Most central banks specify a range rather than single numbers and these ranges are typically established for multiple horizons ranging from one to four years. The overriding announced goal of inflation targeting central banks is typically "price stability", usually defined to be an inflation rate of about $2 \%$. (Ibid., p. 99).

The degree to which the central bank is formally accountable to meeting its targets varies. In New Zealand, for example, law links the tenure of the central bank governor to the inflation targets whereas in other countries, there are no legal or explicit sanctions. Rather, the prestige of the central bank and its governors, and their future job prospects in the private sector are presumably at stake (Ibid., p. 100).

Despite the language emphasizing inflation control as the overriding goal of monetary policy, inflation targeting banks have to some degree accommodated concerns for short-term stabilization objectives, especially with respect to output, exchange rates and, more recently, financial stability. (Ibid., p. 101) This accommodation is accomplished in a number of ways: by using a price index that excludes some particularly volatile elements, such as food and energy; by specifying the target as a range; by occasionally adjusting targets to reflect unusual events such as large supply shocks.

Nonetheless, it is important not to lose sight of the fact that even though inflation targeting central banks do sometimes take into account short term stabilization objectives, inflation is still far and away the overriding concern. In most inflation targeting regimes, "the central bank publishes regular, detailed assessments of the inflation situation, including current forecasts of inflation and discussion of the policy response that is needed to keep inflation on track."(Ibid., p.102) By contrast, if unemployment, investment promotion or employment growth were the "overriding objective" of central bank policy, one would presumably observe the central bank publishing regular detailed assessments of the unemployment situation, including current forecasts of unemployment and a discussion of the policy response that is needed to keep unemployment on track. Stabilizing prices, though a secondary objective, would get much less attention. It is clear that the in such a world, the policy atmosphere would be entirely different. (See below for further discussion of this point). 
Inflation targeting is usually associated with changes in the law, that enhance the independence of the central bank (Ibid., p. 102; Mishkin and Scmidt-Hebbel, 2001, p. 8). Some economists draw a distinction between goal independence and instrument independence with the former giving the central bank the ability to set its own policy targets, and with the latter only giving the central bank the ability to choose the means by which to achieve the goals established by the government (Debelle, 1994). This distinction may not always be significant in practice. Even where changes in law formally only enhance the "instrument" independence of the central bank, in practice, in most cases the goal independence of central banks is apparently increased as well. (Bernanke and Mishkin, 1997, p. 102).

Advocates of inflation targeting claim that targeting is associated with more central bank independence, and at the same time, more accountability. This apparent contradiction is at the heart of the political economy of inflation targeting. The key question, of course, is this: to whom does inflation targeting make the central bank accountable? If the central bank becomes independent, then it would seem that it would be accountable to nobody but itself. How can advocates then claim that along with independence comes accountability?

The solution to this paradox is, of course, that inflation targeting and central bank independence makes the central bank less accountable to the government, and more accountable to the financial markets and those who operate in them. (Epstein, 1994; Blinder, 1998).

Advocates try to get around this paradox by drawing the distinction between instrument independence, in which the central bank controls monetary policy instruments and goal independence, in which the central bank sets the goals of monetary policy.(Debelle and Fischer (1994); Fischer (1994). Most economists have come to the idea that, perhaps, society, (i.e., the government) "ought" to set the goals of monetary policy and the central bank should have "instrument" independence. However, in the end this notion is meaningless since the whole point of inflation targeting is to determine the goal: low inflation.

But even here things aren't so simple, and the arguments get increasingly convoluted. Mishkin and others makes a distinction between the "long-run" inflation target, which should be set by "society" and the medium-term inflation target, which is really the operational target (since " in the long run....."). Here, Mishkin argues that the central bank should set the medium run inflation target. So, even here, many advocates only pay lip service to goal setting by the "government".

It seems clear that the sophisticated advocates of inflation targeting want, in a sense, to have their "cake and eat it too". They want to be able to claim the advantages of rules - such as enhanced credibility, reduced discretion and increased insulation from the political process- without bearing the well known costs of inflexible rules or appearing to be "undemocratic". Indeed, we will see that, even by the evidence developed by 
inflation targeting advocates themselves, inflation targeting has not been able to deliver on the presumed benefits of a targeting approach: namely, enhanced credibility and a reduced costs of lowering inflation. (Bernanke et al., 1999).

\subsubsection{Evidence on Inflation Targeting}

To summarize, the major claims made in favor of inflation targeting are:

1. It will reduce the rate of inflation.

2. It will enhance the credibility of policy.

3. By enhancing the credibility of policy, it will reduce the "sacrifice ratio" associated with contractionary monetary policy. That is, it will lower inflation with fewer costs in lost output or increased unemployment.

What then is the evidence on the impact of inflation targeting? There is some evidence that inflation targeting does succeed in reducing the rate of inflation. But the important question is, does it reduce the costs associated with lowering inflation.

A line of empirical research on credibility effects has consequently focused on the behavior of inflationary expectations and employment costs of anti-inflationary policy under an inflation-targeting monetary regime. Laubach (1997) examines survey evidence and long-term nominal interest rates and find no evidence that the introduction of inflation targets affects expectations of inflation. He argues that in most cases inflationary expectations have come down only as a result of a consistent and successful past record of maintaining low inflation. Announcement of inflation targets had no significant effect on expectations of inflation nor did the adoption of an inflationtargeting monetary regime, inflation expectations do not come down immediately (Mishkin, 1999).

Most important, perhaps, there is virtually no evidence of a reduction in the output loss associated with anti-inflationary policy in countries with inflation targeting. On the basis of the empirical work on the consequences of inflation targeting in Australia, New Zealand and Canada by Blinder (1998) and Debelle (1996) states, "nor does the recent experience of OECD countries suggest that central banks that posted inflation targets were able to disinflate at lower cost than central banks without such targets."(Blinder, 1998:63) Similar results are obtained in Posen (1995) who found little evidence that inflation targeting has significantly reduced the employment costs of reducing inflation.

Similarly, Campillo and Miron (1997) find that "institutional arrangements do not by themselves seem to be of much help in achieving low inflation. Economic fundamentals, such as openness, political instability and tax policy seem to play a much larger role." (Campillo and Miron, 1997, p. 356). 
One exception to this evidence is the work of Corbo, et. al. (2000) who conclude that the sacrifice ratios have declined in emerging markets after adopting inflation targeting. They also find that output volatility has fallen in both emerging and industrialized economies after adopting inflation targeting to levels that are similar to (and sometimes lower than) those observed in industrial countries that not target inflation.

But another recent study by Cecchetti and Ehrmann (2000) comes to the opposite conclusion:

"Our results suggest that both countries that introduced inflation targeting, and nontargeting European Union countries approaching monetary union, increased their revealed aversion to inflation variability, and likely suffered most increases in output volatility as a result."

In the end, Bernanke and colleagues' summary is most telling:

.Inflation targeting is no panacea ... it does not enable countries to wring inflation out of their economies without incurring costs in lost output and employment; nor is credibility for the central bank achieved immediately on adoption of an inflation target. Indeed, evidence suggests that the only way for central banks to earn credibility is he hard way: by demonstrating that they have the means and the will to reduce inflation and to keep it low for a period of time. (Bernanke, et. al, 1999, p. 308.) Moreover, overall...we must admit that the economic performance of the non-targeters over the period considered is not appreciably different from that of the inflation targeters...While in all the inflation-targeting countries, inflation remains unexpectedly low as GDP growth returns to its predicted path, the same is true for (non-targeters) Australia and the United States. (Ibid. p. 283) In short, inflation targets are not a necessary condition for sustaining low inflation...(and)...even for countries with a long record of credible targeting, reducing inflation comes at the price of significant output reductions in the short run. (Ibid. p. 282)

Still, Bernanke, et al. are supportive of the idea that inflation targeting can provide a very useful framework for policy. On the basis of all this evidence, however, it is difficult to see where this support derives from.

However, as we discussed above, there is evidence that inflation targeting plus central bank independence does tend to reduce the inflation rate, even in developing countries, which, presumably, is one of the main goals of both central bank independence and inflation targeting. Hence, inflation targeting and central bank independence seem to 
lead to lower inflation, but they do so at considerable cost. Why are central bankers and governments willing to pay these costs?

\subsubsection{The Costs of Inflation}

Considering the almost exclusive focus of recent monetary theory and practice on fighting inflation, it is remarkable that very little is known about the short-term and long term costs of inflation. And indeed, what is known suggests that the costs of moderate inflation - inflation under 10 or $20 \%$-- are, at most, low.

As a theoretical matter, it is not hard to see why the costs of steady inflation - at any rate - would be moderate. Inflation causes people to economize on cash balances. But, in most general equilibrium models of the economy, cash balances play no obvious crucial role. So-called shoe leather costs - having to go to the bank often - can take a toll, but not a very big one. With computer management of accounts and ATM machines, these costs must be small to the point of vanishing. Walsh (1998) cites estimates which suggest that increases in inflation in the U.S. from $3 \%$ to $10 \%$ would cost about $1.3 \%$ of GDP whereas the lost output associated with reducing inflation from $10 \%$ to $3 \%$ was calculated at about $16 \%$ of GDP. Hence, the cost of reducing inflation was many orders of magnitude greater than the costs of inflation itself.

Economists have also looked at correlations between inflation and measures of real economic activity to attempt to judge the size of the impact of inflation. Barro (1995), for example, finds that inflation under $10 \%$ has no negative impact on economic growth. We will present some more evidence below which supports and expands this view. ${ }^{3}$

\subsubsection{New Evidence on the Impact of Inflation}

This section will discuss the impact of inflation on real economic variables in two data a sets: one is a set of countries which, according to their levels of GNP per capita, are semi-industrialized countries; the other is a larger data set, including countries at all income levels. The goal is to assess the impacts of different levels of inflation on significant economic outcomes.

This analysis has two parts. In the first I summarize the results from our previous study that looked at a sample of semi-industrialized economies and show the relationship between inflation and a variety of measures for these countries.(Epstein and Maximov, 1999) In the second section, I generalize this approach and present some econometric results based on a sample of 70 industrialized, semi-industrialized and poorer countries. ${ }^{4}$ The results of the two sections are broadly consistent with each other: moderate rates of inflation seem to have no negative impacts on broad indicators of economic growth, and may, indeed, be associated with positive impacts.

\footnotetext{
3 See also Bruno and Easterly (1996).

${ }^{4}$ For an earlier version, see Epstein (2000).
} 


\subsubsection{Semi-Industrialized Countries ${ }^{5}$}

To conduct this study, we obtained data for 37 countries classified as "upper middle income" by the World Bank according to its estimates of 1997 GNP per capita. The selected data covers the time period from 1980 to 1997 (the latest year for which data was available in the World Bank's World Development Indicators 1999). In that study we found that:

1. Moderate rates of inflation, under $20 \%$ or so, appear to have no clear impact on most real economic variables such as economic growth, investment, inflows of foreign direct investment and similar variables.

2. High rates of inflation, well over $20 \%$, do appear to have negative real impacts.

3. The impact of inflation on export competitiveness depends on the nature of the exchange rate regime.

4. Disinflation has a mixed effect on real economic variables. In some cases, reducing inflation can have significant negative impacts.

The Impact of Inflation on economic growth in "upper middle income countries"

For the 1980's there clearly seems to be a negative relation between high rates of inflation and per capita GNP growth. But for inflation rates below $20 \%$ or so, there is no clear relation between inflation and growth. In the 1990's, the negative relationship between inflation and economic growth is unclear even for very high inflation rates.

\section{The Impact of Inflation on Domestic and Foreign Investment:}

There is a similar pattern in the relationship between inflation and investment growth.

There is a negative relationship between very high rates of inflation and growth rates of investment, and no discernable relationship between moderate rates of inflation and investment in the 1980's. In the 1990's, even the negative relationship associated with high rates of inflation seems to disappear. Moreover, disinflations between the 1980's and 1990's is associated with negative impacts on gross domestic investment.

Turning now to private investment, there is a negative impact between changes in inflation and changes in private investment. Large increases in inflation rates are associated with lower increases in investment, and declines in the rate of inflation appear to be associated with increases in private investment rates. The difference between these two sets of relationships is primarily explained by the differences in the behavior of private and public investment.

The relationship between inflation and foreign direct investment is similar to the pattern associated with gross domestic investment. Very high rates of inflation appear to be negatively associated with foreign direct investment net inflows (FDI), whereas moderate rates appear to have no relationship, both in the 1980's and in the 1990's.

\footnotetext{
${ }^{5}$ This draws on Epstein and Maximov (1999)
} 
Moreover, disinflations appear to have no obvious advantages in terms of attracting foreign direct investment.

\section{$\underline{\text { Inflation and Exports }}$}

The relationship between inflation and export growth in 1980's is similar: high rates of inflation are associated with lower rates of growth of exports; moderate rates seem to have no clear relationship. In the 1990's there is a positive relationship between inflation and export growth. An important intervening variable may be the exchange rate arrangements. Apparently, countries with high inflation can experience rapid growth in exports if they let their exchange rates float. Moreover, declines in inflation between the 1980's and 1990's were just about as likely to be associated with declines in export growth as increases in it.

\subsubsection{Econometric Analysis of larger data set}

Here I present results of some simple econometric estimates of the impact of inflation. I look at a larger sample of countries which includes the middle income countries discussed above, as well as high and low income countries. The sample includes 70 countries and uses annual data from 1960 to 1997.

Table 9 reports ordinary least squares regressions of the impact of various independent variables, including inflation, on the rate of per capita economic growth. The central result for purposes of this paper is that inflation, far from having a negative impact on economic growth, seems to have a positive impact. These results should be taken with a grain of salt because of possible problems of endogeneity. But there is certainly no support for a negative impact of inflation on economic growth in these data. 
Table 9

Economic Growth and Inflation

Dependent Variable: Rate of Growth of Real Per Capita GNP

(Ordinary Least Squares)

\begin{tabular}{|c|c|c|c|c|}
\hline $\begin{array}{l}\text { Independent } \\
\text { Variable }\end{array}$ & $\begin{array}{l}1960- \\
1997\end{array}$ & $\begin{array}{l}1970- \\
1997\end{array}$ & $\begin{array}{l}1980- \\
1997\end{array}$ & $\begin{array}{l}1990- \\
1997\end{array}$ \\
\hline Inflation & $\begin{array}{c}.037 \\
(3.09)\end{array}$ & $\begin{array}{r}.05 \\
(4.45)\end{array}$ & $\begin{array}{l}.056 \\
(4.6)\end{array}$ & $\begin{array}{l}.01 \\
(1.95)\end{array}$ \\
\hline $\begin{array}{l}\text { Growth of } \\
\text { Gross Domestic } \\
\text { Investment }\end{array}$ & $\begin{array}{c}.16 \\
(12.6)\end{array}$ & $\begin{array}{c}.17 \\
(14.3)\end{array}$ & $\begin{array}{l}.17 \\
(13.2)\end{array}$ & $\begin{array}{c}.151 \\
(10.61)\end{array}$ \\
\hline Export Growth & $\begin{array}{r}.046 \\
(2.36)\end{array}$ & $\begin{array}{l}.05 \\
(2.2)\end{array}$ & $\begin{array}{r}.065 \\
(2.57)\end{array}$ & $\begin{array}{l}.089 \\
(3.4)\end{array}$ \\
\hline $\begin{array}{l}\text { Foreign Direct } \\
\text { Investment }\end{array}$ & $\begin{array}{l}-.15 \\
(-.84)\end{array}$ & $\begin{array}{l}-.02 \\
(-.9)\end{array}$ & $\begin{array}{l}-.21 \\
(-1.3)\end{array}$ & $\begin{array}{l}.26 \\
(2.7)\end{array}$ \\
\hline $\begin{array}{l}\text { Private Investment } \\
\text { Share }\end{array}$ & $\begin{array}{c}-.03 \\
(2.45) \\
\end{array}$ & $\begin{array}{c}-.03 \\
(2.2)\end{array}$ & $\begin{array}{c}-.04 \\
(-2.52)\end{array}$ & $\begin{array}{c}-.03 \\
(3.57)\end{array}$ \\
\hline $\begin{array}{l}\text { Central Bank } \\
\text { Independence }\end{array}$ & $\begin{array}{r}5.7 \\
(1.8)\end{array}$ & $\begin{array}{r}4.09 \\
(1.55) \\
\end{array}$ & $\begin{array}{l}5.18 \\
(1.9)\end{array}$ & \\
\hline Corruption & & $\begin{array}{l}-.17 \\
(1.6)\end{array}$ & $\begin{array}{l}-.11 \\
(-.9)\end{array}$ & $\begin{array}{l}-.17 \\
(-1.8)\end{array}$ \\
\hline Democracy & & $\begin{array}{r}-.15 \\
(2.43) \\
\end{array}$ & $\begin{array}{l}-.18 \\
(-2.7)\end{array}$ & $\begin{array}{l}-.11 \\
(-1.8)\end{array}$ \\
\hline $\begin{array}{l}\text { Country Fixed } \\
\text { Effects }\end{array}$ & Yes & Yes & No & No \\
\hline Year Fixed Effects & Yes & Yes & Yes & No \\
\hline Adjusted R-Square & .43 & .60 & .60 & .48 \\
\hline $\mathrm{D}-\mathrm{W}$ & 1.65 & 1.75 & 1.73 & 1.1 \\
\hline $\mathrm{N}$ & 249 & 194 & 184 & 206 \\
\hline
\end{tabular}

T-statistics in parentheses. For data definitions and sources, see Table 1 and Epstein, 2002, Appendix B. 
There are several other results worth mentioning. Foreign direct investment, as a share of GNP has no impact on growth, except for the final period, 1990-1997, where it seems to have a positive impact. Private investment, as a share of total gross domestic investment, seems to have a negative impact on growth. The measure central bank independence is a measure of legal independence taken from Cuikerman (1992); it is measured on a scale of 0 to 1, with 0 being complete independence and 1 being complete lack of independence from the government. Hence, these regressions suggest that less independent central banks are better for economic growth. The measure for corruption is on a scale of 0 (clean) to 10 (most corrupt). There is some evidence that the more corrupt, the less rapid is economic growth.

\subsection{Conclusion}

In sum, there is little or no evidence that inflation targeting provides special benefits as a monetary operating tool. Moreover, it appears to have significant costs in terms of higher real interest rates and slower economic growth. Moreover, these costs are paid to dramatically lower inflation. Yet, moderate rates of inflation have no apparent costs. In short, there must be a better way to conduct monetary policy.

\section{Employment Targeting: An Alternative to Inflation Targeting}

\subsection{Introduction}

The empirical evidence of the previous sections suggest that there is very little reason to make inflation targeting the basis for monetary policy. The elevation of inflation targets over all other goals of policy -- the hallmark of inflation targeting -- seems to reflect more the power and influence of rentier interests than a sober approach based on the needs of the economy. If inflation targeting does not appear to be a promising approach to monetary policy, what should the approach be? In my view, a better one would embody the following principles:

\section{Context Appropriate Monetary Policy}

Central bank policy goals and operating procedures must be based on the structure and needs of the particular economy at hand: no generic, one-size fits all approach, is likely to be appropriate to every situation.

\section{Real Economy Oriented Monetary Policy}

A single-minded focus on inflation, especially in countries with high levels of unemployment and underemployment is a wrong-headed and costly approach. Policy should recognize that very high rates of inflation can have significant costs, but that short of that, policy must also be oriented toward promoting investment, raising employment growth and reducing unemployment. Hence, the targets of monetary policy should include not just inflation but important real variables such as employment growth and investment. 


\section{Transparency and Accountability}

Taking a leaf from the targeting approach, central banks should be made more accountable to the public by making their objectives and approaches more transparent. They should tell the public what their targets for monetary policy are. They should describe the economic assumptions underlying their plans to reach those targets. And if they do not reach them, they should explain why and describe their plans for achieving them in the next period. And most importantly, the goals of the central bank should be determined by a democratic process.

\section{Policy Flexibility}

A fundamental fact is that there is a great deal of uncertainty concerning the underlying structure of the economy and about the nature of national and international shocks at any particular time. Hence, adherence to any target -- inflation, employment growth or investment -- has to be a flexible adherence. Rigid application of any target can easily lead to serious policy errors. For example, a supply shock might be mistaken for a demand shock, or a deviation from a target might be a result of a fundamental structural change rather than a change within a particular structure.

\section{Supporting Institutions}

Central bank policy is no panacea. Other important supporting institutions are also required. For example, policies to reduce the massive surges of financial capital into and out of economies are often required to create the space to allow for productive central bank policy. Strong tax institutions to enable the government to raise the revenue it needs to fund important public investments are crucial. Public financial institutions to channel credit in support of productive investment are needed. While a discussion of these supporting institutional changes is well outside the scope of this paper, it is important to understand that no central bank policy framework can succeed on its own. (See Pollin, 1998, for an enlightening discussion of these issues.)

\subsection{Employment Growth as a Goal for Monetary Policy}

An example of a much better target for monetary policy is employment growth. This particular target will be especially attractive in a country such as South Africa with high levels of unemployment and underemployment. Under this approach, an employment growth target would be chosen, subject to an inflation constraint, where the inflation constraint is no lower than necessary.

The Role of Inflation in Employment Targeting: 
As the last point makes clear, inflation is not ignored in this employment targeting approach. But it assumes its rightful place in the hierarchy of goals: it operates as a constraint on the primary goal. Of course, the government can choose an inflation constraint no higher than the $6 \%$ rate that is the top of the current inflation targeting range. But then, the onus will be put on the Reserve Bank to explain why it did not reach the employment growth target and to develop policies to reach the target subject to the inflation constraint. This is in sharp contrast to the current situation, where the Reserve Bank has no responsibility at all to design policies to help achieve employment growth.

\subsection{How would the Employment Targeting Framework Operate?}

The central bank, in conjunction with the government, would estimate a feasible target range for employment growth, taking into account the rates that are consistent with moderate inflation. Based on the estimate of the relationship between the central banks' policy instrument and employment growth, the central bank will try to achieve its target. Note that many of the problems that arise will be similar to those that arise with inflation targeting. For example, what is the best instrument to use? What is the best way to measure employment growth? What should be done about uncertainty? There is no reason to believe that these issues will be any harder - or easier to deal with-than in the inflation targeting case.

\section{Objections to Employment Targeting}

The major objection to employment targeting from mainstream economists is also the least valid: it is the claim that only nominal variables can be affected by monetary policy, at least in the long run. But Keynes' point about the long run is still true; and there is plenty of evidence that central bank policy can have significant impacts on employment and other real variables, such as investment (eg. Ball, 1999).

There will be other objections to employment targeting. Many economists will argue that the association between central bank policy and employment growth is simply too lose to base policy on. But Bernanke et al, and other advocates of targeting have admitted that the connection between central bank policy and inflation is also lose and variable. (Bernanke, et. al. 1999) There is simply no macroeconomic variable worthy of interest, including inflation, that is perfectly controlled by the central bank.

Some economists might argue that our approach is bound to fail, and, indeed, is no different from outdated approaches to central bank policy. Many will claim that it is "old-fashioned". However, our approach builds on recent discussions of the impact of inflation and inflation targeting. In particular,

1. it recognizes that high rates of inflation (over 15 -20\%) can have significant, negative impacts on important real variables and therefore high rates of inflation should be avoided. 
2. along with the new literature, it supports the idea that transparency, clear objectives, and clear modus operandi is important for good policy.

Moreover, there is nothing wrong with being "old fashioned" if the old fashion makes more sense than the new one. What this approach rejects is the notion that low inflation should be the single-minded goal of policy. And it rejects the pseudoscientific claim that a gimmick such as inflation targeting can deliver a credibility free lunch to society. The main free lunch available to most economies only results from putting to work unemployed and under-employed resources. The inflation target advocates, by making false promises, and in some cases even bullying countries to adopt such targets, serve to undermine the one free lunch that most economies are likely to have: putting people, who do not have jobs, back to work.

\subsection{The Indirect Advantages of Employment Targeting}

There are several extremely important indirect advantages of the employment targeting framework which themselves will contribute in a crucial way to the framework's success. These indirect advantages involve the accumulation of new knowledge about the connections between monetary policy and employment, and the generation and implementation of new ideas about to generate more employment and economic growth. Both of these positive outcomes will stem from focusing the attention of the Central Bank, with its enormous human and financial resources, on the key issue of employment growth.

Making employment growth a target of monetary policy will induce a profound shift in the attitude and the activities of the central bank. It will begin to assign its economists to study the relationships between monetary policy and employment growth; it will study what monetary policy instruments are best used to achieve employment growth; it will organize conferences on employment growth and monetary policy. It will give promotions and more resources to members of its staff that make breakthroughs in the understanding of these connections. It will lead the Reserve Bank to link up with others outside the Bank who have knowledge and experience with respect to employment generation and its relationship to financial variables.

The creation of an employment targeting framework will not only lead the Reserve Bank to generate more knowledge about the relationship between monetary policy and employment growth. It will lead the bank to design new programs to help it reach it targets. To be sure, lowering interest rates, as I have suggested earlier, could have an important impact on investment and expansion behavior by many firms, large and small, in South Africa. But the Reserve Bank will also find that, in order to contribute to more employment generation subject to an inflation constraint, it will need additional instruments of monetary policy.

\subsubsection{Targets and Instruments}

As Tinbergen argued in his classic piece on policy making, one needs at least 
as many independent instruments as targets to reach one's objectives. If the Reserve Bank were to adopt an employment targeting approach, in which it also had to meet an inflation constraint, then in effect there are up to two targets and only one instrument, the interest rate. In this situation, the Reserve Bank will undoubtedly search for more instruments with which to reach its targets.

There are a number of useful possibilities. Among the most promising are various mechanisms of credit allocation. Examples of these include: asset based reserve requirements, support for pooling and underwriting small loans, utilizing the discount window in support of employment generating investments (see Pollin, 1994, 1995, 1998 for discussions of this approach). Asset based reserve requirements are an effective tool for creating incentives for banks and other financial institutions to invest in socially productive assets. For example, the central bank would list a set of employment generating investment which would have lower reserve requirements, relative to investments which have lower social priority, such as speculative investments. (Pollin, ibid) Another possible instrument would be creating liquidity and risk sharing institutions for loans to small businesses which have promise to generate employment but which now have restricted assets to financial markets. An example of this type of policy would be to provide financial and administrative support for asset backed securities which would take loans to small businesses and other employment generating lending, bundle these investments, and sell them as securities on the open market, much as Ginnie Mae and Fannie Mae do in the United States in the housing market.

As a final example, the Reserve Bank could open a special discount window facility, in which it would offer credit, guarantee, or discount facilities to institutions which are on-lending to firms and cooperatives which have promising employment generating opportunities.

\subsubsection{Employment Targeting Through A Gender Lens}

Among the great advantages of combining credit allocation mechanisms with the employment targeting approach is that it provides the policy flexibility necessary to succeed in varying institutional contexts. For example, where female waged employment is important for social welfare, using a gender lens will be crucial for designing effective macroeconomic policy in general and employment targeting monetary policy in particular. In these contexts, the central bank could design asset based reserve requirements to generate more female employment; alternatively, the central bank could give preferential access to the discount window for financial institutions investing in or lending to organizations which will generate more, better, female employment. Indeed, even in the absence of a prior understanding of the importance of women's wage employment, in these situations, an employment targeting central bank will likely discover on its own the importance of using a gender lens in macroeconomic policy if it is going to achieve its employment generating targets. This is an excellent example of the beauty of implementing an employment targeting approach: it will force the central bank to learn much more about the nature of the labor force and how to increase gainful employment., which, in many societies, will mean that it will learn much more about the 
female labor force.

\subsubsection{Getting There from Here}

Of course, the specifics of any such policies would require serious and substantial research and thought. But the point is that having an employment growth target would focus the energy of the central to develop these ideas. Drawing on international experiences and the specific institutional context of South Africa, the research would certainly bear fruit.

Finding additional monetary policy instruments would have an additional benefit: it would help to insulate socially important segments of the South African financial markets from the international capital markets. Along with exchange controls and other capital management techniques, credit allocation techniques in a small open economy like South Africa can create space for itself within the turbulent waters of international financial markets.

\section{Capital Account Management Techniques}

\subsection{The Need for Capital Management Techniques}

In order to make employment targeting work, the central bank will have to confront the external constraint generated by speculative financial flows and their impact on the exchange rate. (For related discussion, see the important work of Pollin,1998). The recent change in global thinking about international capital market regulation will likely facilitate this process.

This evolution is represented by the IMF's official thinking on the subject. Five years ago, before the Asian financial crisis, the IMF was considering making complete capital account convertibility a requirement for full membership in the IMF. (Fischer, et. al. 1998) Today, the IMF has dropped this plan, and even concedes that some forms of controls over capital inflows might be useful for developing countries I some circumstances (Ariyoshi, et. al., 2000). This change not only is an acceptance of reality namely that many developing countries, including some of the most successful ones, (including China, Malaysia, Taiwan and South Korea) have capital controls or had them during their periods of most rapid expansion. It is also an acceptance of the real problems of instability, crises and contagion that stems from completely free international capital mobility. The Asian financial crisis of 1997, and the current crisis in Argentina are grim reminders of these difficulties.

In this context, it is no longer seen as a grave affront to financial orthodoxy to adopt some form of capital account management technique. And in fact, increasingly, developing countries are acting in a prudent fashion to retain some control over their capital accounts. (See Ariyohsi, et al. 2000 for a general description of these techniques.)

The possible benefits from applying such techniques are: 
1) Reducing the instability and possible crises arising from volatile international financial flows.

2) Insulating domestic interest rates, credit conditions and/or the exchange rate from international credit conditions,

and

3) Making some room for expansionary monetary policy.

Case studies of the impact of these controls in different contexts are proliferating. (See, for example, Rajaraman, 2002 on India and Malaysia; Kaplan and Rodrik 2002 on Malaysia; de Palma 2001 on Chile ). These studies suggest that, administered properly, capital management techniques can succeed in all three of these goals. A large number of cross country studies have also looked at the impact of capital controls (See Eichengreen, 2002, for a recent survey). These studies suffer from many problems, including getting a good index for controls. But they too give some support to the usefulness of controls.

\subsection{Capital Management Techniques in South Africa}

South Africa has a system of exchange controls. (see Bruce-Brand, 2002 for an overview). Since the end of the apartheid regime, the Government has been slowly liberalizing the capital account, first with the abolition of the financial rand in March of 1995 and, gradually over the last 5 or 6 years. In October of this past year, the exchange control enforcement was tightened, in response to the rapid decline of the Rand, but according to the Governor of the Reserve Bank, "the South African authorities remain committed to the orderly and gradual process of relaxation of exchange controls" (Mboweni, 2002, p. 40). The decision to liberalize controls was a controversial one and hotly contested. In light of the problems facing South Africa and the financial turmoil it has been experiencing recently, it seems very important to revisit the decision to liberalize the exchange controls. As discussed earlier in this paper, the benefits to be achieved from financial openness are much smaller than is commonly believed. Moreover, exchange controls can help to maintain the macroeconomic stability that forms the basis for growth of a country's production and export capacity.

The South African Government should, in addition, consider additional tools to manage the capital account, and thereby insulate the domestic financial markets from international markets. (See Grabel, 2002, for example, for a discussion of possible techniques.) Among the most promising ones are "speed-bumps", namely increased taxes

on inflows and outflows of funds, which become increasingly important as the quantity controls have been relaxed.

Speed-bumps on inflows have become most popular. A standard model is the Chilean unremunerated reserve requirement. URR is a requirement to hold an 
unremunerated fixed-term (mostly 1-year) reserve at the Central Bank, equivalent to a fraction of capital inflows of selective categories. Hence the URR is equivalent to a tax per unit of time that declines with the permanence or maturity of the affected capital inflows. The quantitative nature of this restriction, i.e. its tax equivalence, is made explicit by its alternative form: foreign investors are alternatively entitled to pay an upfront fee determined by the product of the relevant foreign interest rate ( $\left.i^{*}\right)$ and the fraction of capital subject to the restriction. (See Gallego, et. al. 1999). Gallego et al. find that, for example, the Chilean controls have been relatively successful in insulating the Chilean economy from financial instability; they have also been successful at keeping a wedge between domestic and international interest rates. They are less sanguine about the impacts over the longer term, but have no hard evidence of deleterious effects I the longer run.

Similar speed bumps can be placed on outflows. Examples are taxes on purchases of foreign exchange, or, in the case of both inflows an outflows, a Tobin Tax. A securities transactions tax (Pollin, et. al., 2002 ) would complement these international speedbumps. As Rajaraman(2002) points out, India and Malaysia, having started in very different spots, have converged on a system in which non-resident flows are relatively free, whereas resident outflows are highly restricted. These are designed to encourage capital inflows, while maintaining control over resident outflows. Some countries, notably China and India, have had much stricter controls for a number of years; and particularly in the case of China, these have contributed significantly to its economic success in recent years.

Obviously, a system of controls for South Africa must be tailored to fit the specific conditions there, and should build on the controls that already exist. The main point, though, is that the policy to liberalize further should be reconsidered in light of the financial crises that have rocked the world since the decision was made to liberalize in 1994-1995. The world financial markets and institutions are much more tolerant now, than they were seven years ago, of countries which attempt to stabilize their economies by reducing the destructive effects of unstable international capital flows by adopting capital flow management techniques. In short, South Africa should not feel compelled by external forces to liberalize.

One possible objection to this argument is the claim that, in order to develop South Africa as a regional financial center, exchange controls need to be liberalized. This is a complex topic worthy of separate consideration. Of course, there are advantages that can be gained from such a role. But there are also clearly risks. Among the reasons Thailand liberalized its financial markets, for example, was to try to become a regional financial center. But liberalizing left the thai economoy vulnerable. Speculative inflows of capital lead to a cycle of over-valued exchange rates and then a currency crash (Taylor, 2002).

It should be recalled that the U.S. became a world financial center in the first part of the $20^{\text {th }}$ century only AFTER its industrial foundation had been laid in the last half of the $19^{\text {th }}$ century. South Africa too much move carefully to make sure its highly diverse 
economy develops in a balanced fashion as it tries, as part of its development strategy not as a dominant part of its strategy -- to develop a major financial center.

\section{Conclusion}

In an already long paper, the conclusion can be brief. Inflation targeting and open capital markets are not the best monetary framework for a country like South Africa with high unemployment and high rates of poverty. Inflation targeting punishes the country with excessively high real interest rates and slow economic growth in the interests of fighting inflation, which at moderate rates has few costs. Liberalizing exchange controls makes the South African economy vulnerable to crises and real interest rate penalties imposed by the international financial markets, with little expected benefit.

A better framework would be an employment targeting framework, in which the Reserve Bank would target employment growth, subject to an inflation constraint. At the same time, the Reserve Bank should develop new tools of monetary policy to enable it to hit this additional target. And maintaining capital account management techniques are essential if South Africa is going to lower real interest rates and channel credit to more productive uses. 


\section{REFERENCES}

Agosin, Manuel R. and Ricardo Mayer. 2000. "Foreign Investment in Developing Countries: Does it Crowd in Domestic Investment?" UNCTAD Discussion Paper No. 146.

Allsopp, Christopher and Andrew Glyn, 1999. "The Assessment: Real Interest Rates", Oxford Review of Economic Policy, Vol. 15, No. 2.

Amsden, Alice. 2001. The Rise of the Rest: Challenges to the West from late-Indusrializtion Economies. New York: Oxford University Press.

Ariyoshi, Akira, et al. (2000). Country Experiences with the Use and Liberalization of Capital Controls, IMF, Washington, DC.

Aron, Janine and John Muellbauer, 2000. Financial Liberalization, Consumption and Debt in South Africa. Center for the Study of African Economies, Working Paper Series, 200022.

Baker, Dean, Gerald Epstein and Robert Pollin. 1993. Transforming the U.S. Financial System: Equity and Efficiency for the $21^{\text {st }}$ Century. Armonk, NY: M.E. Sharpe.

Baker, Dean, Gerald Epstein and Robert Pollin. 1998. Globalization and Progressive Economic Policy. Cambridge, UK: Cambridge University Press.

Baker, Dean, Gerald Epstein and Robert Pollin, 1998.Introduction. Globalization and Progressive Economic Policy. Cambridge: Cambridge University Press.

Barro, Robert. 1995. Inflation and economic growth. Bank of England Quarterly Bulletin 35: 166-176.

Ball, Laurence, 1999. "Aggregate Demand and Long-Term Unemployment”, Brookings Papers on Economic Activity, 1999, pp. 189-253.

Bernanke, Ben S., Thomas Laubach, Adam S. Posen and Frederic S. Mishkin. 1999. Inflation Targeting: Lessons from the International Experience. Princeton, NJ: Princeton University Press.

Bernanke, B.S. and F. S. Mishkin. 1997. Inflation targeting: a new framework for monetary policy? Journal of Economic Perspectives 11, no. 2, Spring.

Blinder, Alan S. 1998. Central Banking in Theory and Practice. Cambridge, MA: MIT Press. 
Blinder, Alan S. 1999. Central Bank Credibility: Why Do We Care? How do we built it? NBER Working Paper, no. 7161.

Braunstein, Elissa and Gerald Epstein. 2002. Bargaining Power and Foreign Direct Investment in China: Can 1.3 Billion Consumers Tame the Multinationals?, mimeo, PERI.

Bruce-Brand, A. M. 2002. Overview of Exchange Controls in South Africa. Statement to the Commision of Inquiry into the Rapid Decpreciation of the Exchange Rate of the Rand. Reserve Bank of South Africa.

Bruno, M. and W. Easterly, 1996. Inflation and Growth: In Search of A Stable Relationship. Federal Reserve Bank of St. Louis Review, 78 (3), pp. 139-46.

Burke, James and Gerald Epstein, 2001. The Internationalization of Production. http://www.umas.edu/peri

Campillo, Marta and Jeffrey Miron. 1997. "Why Does Inflation Differ Across Countries?,” in Monetary Policy and Low Inflation, Christina D. Romer and David Romer, eds., Chicago: The University of Chicago Press.

Castelejin, A.J.H. 2001. South Africa's Monetary Policy Framework, South African Reserve Bank, Research and Legal Services Department.

Cecchetti, Stephen and Michael Ehrmann, 2000. Does Inflation Targeting Increase Output Volatility? An International Comparison of Policymakers' Preferences and Outcomes? Central Bank of Chile Working Papers, No. 69.

Change, Ha-Joon. 2002. Kicking Away the Ladder: Development Strategy in Historical Perspective. London: Anthem Press.

Chang, Roberto and Adres Velasco. The 1997-98 Liquidity Crisis: Asia Versus Latin America. Central Bank of Chile Working Papers, No. 120.

Corbo, Vittorio, Osca Landerretche and Klaus Schmidt-Hebbel. 2001. Does Inflation Targeting Make a Difference? Central Bank of Chile Working Papers, No. 106. http://www.bcentral.cl/Estudios/DTBC/doctrab.htm

Crotty, J., and Dymski, G. 1998. Can the global neoliberal regime survive victory in Asia?', International Papers in Political Economy, vol. 5, no. 2

Crotty, J., and Epstein. G. 1996. In defence of capital controls, in Panitch, L. (ed), Are There Alternatives? Socialist Register 1996, London, Merlin Press 
Crotty, J., and Epstein. G. 1999. A defense of capital controls in light of the Asian financial crisis, Journal of Economic Issues, vol. 33, no. 2

Cukierman, Alex. 1992a. Central Bank Strategy, Credibility, and Independence: Theory and Evidence. Cambridge, MA: The MIT Press.

Debelle, Guy. 1996. The end of three small inflations: Australia, New Zealand, and Canada. Canadian Public Policy 22: 56-78.

Debelle, Guy and Stanley Fisher. 1994. How independent should a central bank be? In Goals, Guidelines, and Constraints Facing Monetary Policymakers, ed. Jeffrey Fuhrer: FRB of Boston Conference Series 38.

Eichengreen, Barry and Andrew Rose (2000). Staying Afloat When the Wind Shifts: External Factors and Emerging-Banking Crises, in Guillermo Calvo, Rudiger Dornbush and Maurice Obstfeld (eds.) Money, Capital Mobility and Trade: Essays in Honor of Robert Mundell, Cambridge, Mass.: MIT Press, 171-206.

Eichengreen, Barry. 2001. International Financial Crises: Is the Problem Growing? mimeo,University of California, Berkeley, August.

Eichengreen, Barry (2001), Capital Account Liberalization: What Do the Cross-Country Studies Tell Us? The World Bank Economic Review. Forthcoming

Epstein, Gerald. 1993. Monetary Policy in the 1990's: Overcoming the Barriers to Equity and Growth", in Gary Dymski, Gerald Epstein and Robert Pollin,eds., Transforming the U.S. Financial System: An Equitable and Efficient Structure for the 21st Century. Armonk, NY: M.E. Sharpe.

Epstein, Gerald. 1994. A political economy model of comparative central banking. In New Perspectives in Monetary Economics: Explorations in the Tradition of Hyman Minsky., ed. G. and R.N. Pollin Dymsky. Ann Harbor, MI: University of Michigan Press.

Epstein, Gerald. 2000. Myth, Mendacity and Mischief in the Theory and Practice of Central Banking. www.umass.edu/peri

Epstein, Gerald. 2002. Financialization, Rentier Interests and Central Bank Policy. www.umass.edu/peri

Epstein, Gerald and Herbert Gintis. 1992. International Capital Markets and the Limits of National Economic Policy. in Tariq Banuri and Juliet Schor, eds. Financial Openness and National Autonomy. Oxford: Clarendon Press

Epstein, Gerald and Maxim Maximov. 1999. A Critique of Inflation Targeting and An Alternative Proposal for the Reserve Bank of South Africa. mimeo. University of Massachusetts, Department of Economics. 
.Fischer, Stanley. 2001. Exchange Rate Regimes: Is the Bipolar View Correct? International Monetary Fund.

Fischer, Stanley, et. al. 1998. Should the IMF Pursue Capital-Account Convertibility? Essays in International Finance. No. 207. Princeton University.

Frey, M.J. 1997. In Favor of Financial Liberalization. Economic Journal. 107 (442), 1.

Gallego, Francisco, Leonardo Hernández and Klaus Schmidt-Hebbel, 1999. Capital Controls In Chile: Effective? Efficient?. Central Bank of Chile, Working Paper.

Gelb, Stephen, 2001. Socio-political Risk, Confidence and Firm Investment in South Africa, mimeo, The Edge Institute, Johannesburg.

Gibson, Bill and Dirk Ernst van Seventer, 2000. Real Wages, Employment and Macroeconomic Policy in a Structuralist Model for South Africa. mimeo, University of Vermont.

Grabel, Ilene. 1997. Saving and the Financing of Productive Investment: The Importance of National Financial Complexes. In Robert Pollin, ed. The Macroeconomics of Finance, Investment and Saving. Ann Arbor: University of Michigan Press, pp. 251-98.

Grabel, I. 2002. Averting crisis?: Assessing measures to manage financial integration in emerging economies," Cambridge Journal of Economics, forthcoming.

Hanson, Gordon H. 2001. "Should Countries Promote Foreign Direct Investment?" UNCTAD G-24 Discussion Paper Series No. 9.

Harrison, Ann E. and Margaret S. McMillan, 2002. Does Direct Foreign Investment affect Domestic Firms Credit Constraints? University of California, Berkeley.

Harrison, Ann E. Inessa Love and Margaret S. McMillan. 2001. Global Capital Flows and Financing Constraints. The World Bank.

Heintz, James, 2002. Capital Accumulation and Macro Policy in South Africa: Political Instability, Distributive Conflict, and Economic Institutions. PERI Working Paper Series, No. 29. http://www.umass.edu/peri

Kahn, B. and G.N. Farrell, 2002. South African Real Interest Rates in Comparative Perspective: Theory and Evidence, South African Reserve Bank, Occasional Paper, No. 17.

Kaplan, Ethan and Dani Rodrik (2001). Did the Malaysian Capital Controls Work?. February, NBER www.nber.org

Laubach, Thomas and Adam S. Posen. 1997. Some comparative evidence on the effectiveness of inflation targeting. Federal Reserve Bank of New York Working Paper 97, no. 14. 
Lewis, Jeffrey D. 2001. Policies to Promote Growth and Employment in South Africa, the World Bank Southern Africa Department, Informal Discussion Papers on Aspects of the Economy of South Africa, No. 16.

Mankiw, N. Gregory. 2001. U.S. Monetary Policy During the 1990's. NBER Working Paper 8471 .

Maximov, Maxim, 1999a. Political Economy of Central Banking in Post-Soviet Russia, mimeo, Department of Economics and Political Economy Research Institute, University of Massachusetts, Amherst.

Maximov, Maxim. 1999b. “A Survey of Empirical Evidence on the Effects of Monetary Policy Credibility", mimeo, Department of Economics and Political Economy Research Institute, University of Massachusetts, Amherst.

Maximov, Maxim. 1999c. "Empirical evidence on Time Inconsistency of Monetary Policy". mimeo, Department of Economics and Political Economy Research Institute, University of Massachusetts, Amherst.

Mboweni, Tito Titus. 2002. Statement to the Commision of Inquiry into the Rapid Decpreciation of the Exchange Rate of the Rand. Reserve Bank of South Africa.

Mishkin, Frederic S. 1999. International experiences with different monetary policy regimes. NBER Working Paper 6965.

Mishkin, Frederic S. and Klaus Sschmidt-Hebbel. 2001. One Decade of Inflation Targeting in the World: What Do We Know and What Do We Need to Know? NBER Working Paper, 8397.

Obstfeld, Maurice and Alan M. Taylor. 2002. Globalization and Capital Markets. NBER Working Paper, \# 8846, March.

Palma, Gabriel, 2000. The Three Routes to Financial Crises: The need for Capital Controls. Center for Economic Policy Analysis (CEPA).

Pil, H and Pradhan, M. 1997. Financial Liberalization in Africa and Asia. Finance and Development, 34 (2).

Pollin, R. N. 1993. Public Credit Allocation Through the Federal Reserve: Why it is needed; How it should be done.", in Baker, Epstein, and Pollin, eds. Transforming the U.S. Financial System.

Pollin, R.N. 1995. Financial structures and egalitarian economic policy. New Left Review 
December: 26-61.

Pollin, R.N., 1998. Can Domestic Expansionary Policy Succeed in a Globally Integrated Environment? An Examination of Alternatives. In D. Baker, G. Epstein and R.N. Pollin, eds. Globalization and Progressive Economic Policy. Cambridge: Cambridge University Press.

Rajamaran, Indira. 2001. Management of the Capital Account: A Study of India and Malaysia. mimeo. UNCTAD.

Rodrik. Dani (1998), Who Needs Capital Account Convertibility?. In Should the IMF Pursue Capital-Account Convertibility? Essays in International Finance. No. 207. Princeton University.

Rodrik, Dani and Andres Velasco (1999), "Short Term Capital Flows," NBER Working Paper no. 7364 (September).

Taylor, Lance, ed. 2001. External Liberalization, Economic Performance and Social Policy. New York: Oxford University Press.

Taylor, Mark P. 1999. Real Interest Rates and Macroeconomic Activity. Oxford Review of Economic Policy, Vol. 15, No. 2.

Walsh, Carl. 1998. Monetary theory and policy. Cambridge, MA: The MIT Press. 